\title{
ANALISA PRODUKTIVITAS PADA PT. PEKEBUNAN NUSANTARA (PTPN) X PG KREMBOONG DENGAN METODE OBJECTIVE MATRIX (OMAX)
}

\author{
Yoniv Erdhianto ${ }^{1)}$, Gatot Basuki HM ${ }^{2}$ \\ 1) Jurusan Teknik Industri, Institut Teknologi Adhi Tama Surabaya \\ 2) Jurusan Teknik Perkapalan, Institut Teknologi Adhi Tama Surabaya \\ Email: yoniv@itats.ac.id, gatotbasukihm@itats.ac.id
}

\begin{abstract}
ABSTRAK
Produktivitas merupakan hal yang sangat perlu dipertimbangkan oleh perusahaan karena produktivitas mempunyai peranan penting dalam pencapaian tujuan perusahaan. Penelitian ini dilakukan guna mendapatkan hasil dari pengukuran rasio produktivitas yang selama ini belum pernah dilakukan, dan selanjutnya hasil dari pengukuran tersebut akan digunakan sebagai upaya peningkatan produktivitas untuk masa yang akan datang di PG Kremboong. Penelitian ini dalam penyelesaian masalahnya menggunakan metode Objective Matrix (OMAX). Pengukuran dengan objective matrix (OMAX) ini didasarkan pada prinsip produktivitas, yaitu berdasarkan sasaran yang secara objektif mengukur unjuk kerja dan fungsi tujuan sebagai target pencapaian kelompok kerja, sehingga dihasilkan pengukuran kuantitatif yang menunjukan sejauh mana tujuan manajemen tercapai. Dari analisa produktivitas di PG Kremboong dengan metode OMAX disimpulkan bahwa, indeks produktivitas terbaik terjadi pada September 2018 sebesar 904 dan terburuk terjadi pada September 2018 sebesar $201 \%$ dan terburuk pada bulan Juni 2018 sebesar -45\%. Indeks perubahan terhadap produktivitas periode sebelumnya dapat diketahui bahwa produktivitas terbaik terjadi pada Juli 2018 sebesar 375\%. Sedangkan untuk produktivitas yang terjadi pada AgustusSeptember 2018 sama-sama memiliki nilai yaitu sebesar $8 \%$. Langkah perbaikan produktivitas guna perencanaan peningkatan produktivitas dimasa yang akan datang adalah dengan cara memprioritaskan kepada rasio yang memiliki nilai paling buruk untuk ditingkatkan.
\end{abstract}

Kata kunci: Produktivitas, .Objective Matrix, Pengukuran Kuantitatif

\section{Pendahuluan}

Produktivitas merupakan hal yang sangat perlu dipertimbangkan oleh suatu organisasi atau perusahaan karena produktivitas mempunyai peranan yang penting dalam pencapaian tujuan dari perusahaan yang bersangkutan. Produktivitas adalah peningkatan dari proses produksi yang telah dilakukan oleh suatu perusahaan [1]. Peningkatan disini berarti perbandingan membaik dari jumlah sumber daya yang digunakan dengan jumlah barang dan jasa yang dihasilkan [2]. Oleh karena itu, produktivitas untuk saat ini bukan sekedar kewajiban yang harus diperhatikan namun harus dipenuhi untuk menjaga produktivitas perusahaan [3]. Salah satu faktor yang dapat mempengaruhi keunggulan dalam bersaing adalah faktor-faktor internal perusahaan. Faktor internal ini sebenarnya cenderung dapat dikendalikan dibandingkan faktor eksternal perusahaan [4]. Salah satu indikator yang mempengaruhi dalam upaya meningkatkan produktivitas yang efektif dan efisien adalah gaya kepemimpinan dan human relation yang diterapkan oleh pimpinan perusahaan, secara umum produktivitas adalah perbandingan atau rasio antara output dan input [5].

PT. PEKEBUNAN NUSANTARA (PTPN) X PG Kremboong adalah perusahaan yang memproduksi gula. Sehingga dalam penelitian ini, produk yang akan dijadikan sebagai hasil (output) adalah gula. Penelitian ini mengangkat masalah tentang manajemen produktivitas di perusahaan dan diharapkan akan menjadi suatu tolak ukur bagi perusahaan untuk mengetahui sejauh mana keberhasilan yang dicapai oleh perusahaan, dengan memanfaatkan sumber daya yang tersedia untuk menghasilkan output yang diharapkan perusahaan.

Penelitian ini dalam penyelesaian masalahnya menggunakan metode Objective Matrix (OMAX). Permasalahan yang dibahas yaitu tentang mengukur rasio produktivitas pada departemen pengolahan di PG Kremboong dan usulan perbaikan apa dalam upaya peningkatan produktivitas dimasa yang akan datang. Data yang diambil pada penelitian ini adalah output produksi, kebutuhan jam kerja, jumlah tenaga kerja, dan energi listrik yang dibutukan dalam pengambilan sampel selama 4 bulan. Alasan mengambil 4 kriteria tersebut adalah karena 4 hal tersebut saling berketerkaitan dalam efektifitas selama proses produksi, agar dapat mempermudah dalam menyelesaikan permasalahan dalam produktivitas.

Copyright (C 2019, Kaizen : Management Systems \& Industrial Engineering Journal ISSN 15222-96806 (print), ISSN $155222-95973$ (online) 


\section{KAIZEN : MANAGEMENT SYSTEMS \& INDUSTRIAL ENGINEERING JOURNAL VOL. 2 NO. 2 TEKNIK INDUSTRI UNIVERSITAS PGRI MADIUN}

\section{Metode Penelitian}

Pengukuran dengan model objective matrix (OMAX) ini di dasarkan pada prinsip produktivitas, yaitu berdasarkan sasaran yang secara objektif mengukur unjuk kerja dan fungsi tujuan sebagai target pencapaian bagi kelompok kerja, sehingga dihasilkan pengukuran kuantitatif yang menunjukan sejauh mana tujuan manajemen tercapai [6]. Model ini juga sering disebut dengan metode matrix sasaran, yaitu metode pengukuran fisik dengan menggunakan tabel matrix yang berisi angka-angka terdefinisi sebagai nilai bobot, nilai skala peringkat atau rangking dari masing-masing indikator [7]. Ada 4 tahap dalam mengembangkan matrik sasaran, yaitu pemilihan kriteria, menetapkan nilai skala, penetapan bobot kepentingan untuk kriteria unjuk kerja, dan mengukur indikator produktivitas.

\section{Hasil dan Pembahasan}

Tahapan penelitian diawali dengan pengumpulan data. Data yang dicatat mulai dari periode bulan juni 2018 hingga bulan September 2018 pada saat giling atau produksi. Data yang diperlukan dalam perhitugan OMAX adalah output produksi gula, . penggunaan listrik, jumlah tenaga kerja di bagian pengolahan dan jam kerja. Hasil pengumpulan data dapat dilihat pada Tabel 1., Tabel 2., Tabel 3., Tabel 4. dan Tabel 5. Keperluan dan kebutuhan terhadap produktivitas di bagian produksi, nilai pembobotan didapatkan dari bagian pengolahan. Adapun nilai yang ditetapkan adalah 1 sampai 10, dimana nilai 10 menunjukkan nilai terbesar dan nilai 1 menunjukkan nilai terkecil. Pada Tabel 6. menunjukkan data pembobotan. Hasil rasio 1 : nilai 8 ini menunjukkan bahwa waktu kerja paling berpengaruh pada output produksi yang dihasilkan. Hasil rasio 2 : nilai 7 ini menunjukkan bahwa tenaga kerja saling berhubungan pada output produksi yang dihasilkan. Hasil rasio 3 : nilai 7 menunjukkan bahwa kebutuhan energi bersifat tentatif pada proses produksi.

Tabel 1.Output Produksi Dalam Periode

\begin{tabular}{|l|c|c|c|}
\hline \multicolumn{1}{|c|}{ Periode } & Output produksi (kg) \\
\hline Periode 1 (Juni) & $1,666,000$ & Periode & Output produksi (kg) \\
\hline Periode 2 (Juni) & $1,268,500$ \\
\hline Periode 3 (Juli) & $2,755,800$ \\
\hline Periode 4 (Juli) & $2,596,000$ \\
\hline
\end{tabular} \begin{tabular}{|l|c|}
\hline Periode 5 (Agustus) & $2,585,000$ \\
\hline Periode 6 (Agustus) & $2,346,000$ \\
\hline Periode 7 (September) & $2,493,500$ \\
\hline
\end{tabular}

Tabel 2. Output Produksi Gula Konversi Bulan

\begin{tabular}{|c|c|}
\hline Bulan & Output produksi $(\mathrm{kg})$ \\
\hline Juni 2018 & $2,934,500$ \\
\hline Juli 2018 & $5,351,800$ \\
\cline { 1 - 3 }
\end{tabular}$\quad$\begin{tabular}{|l|c|}
\hline Agustus 2018 & Output produksi (kg) \\
\hline September 2018 & $4,931,000$ \\
\hline
\end{tabular}

Tabel 3. Penggunaan Listrik

\begin{tabular}{|c|c|}
\hline Bulan & Listrik $(\mathrm{KWH})$ \\
\hline Juni 2018 & 72,520 \\
\hline Juli 2018 & 116,823 \\
\hline
\end{tabular}

Tabel 4. Jumlah Tenaga Kerja di Bagian Pengolahan

\begin{tabular}{|c|c|c|c|}
\hline Bulan & Orang & Bulan & Orang \\
\hline Juni 2018 & 418 & Agustus 2018 & 418 \\
\hline Juli 2018 & 418 & September 2018 & 418 \\
\hline
\end{tabular}

Tabel 5. Jam Kerja

\begin{tabular}{|c|c|}
\hline Bulan & Jam Kerja \\
\hline Juni 2018 & $19 \times 24=456$ \\
\hline Juli 2018 & $26 \times 24=624$ \\
\hline
\end{tabular}

\begin{tabular}{|c|c|}
\hline Rasio & $\begin{array}{c}\text { Nilai Kepentingan } \\
\text { Pembobotan }\end{array}$ \\
\hline 1 & 8 \\
\hline
\end{tabular}

Tabel 6. DataPembobotan

\begin{tabular}{|c|c|}
\hline Rasio & $\begin{array}{c}\text { Nilai Kepentingan } \\
\text { Pembobotan }\end{array}$ \\
\hline 2 & 7
\end{tabular}$\quad$\begin{tabular}{|c|c|}
\hline Rasio & $\begin{array}{c}\text { Nilai Kepentingan } \\
\text { Pembobotan }\end{array}$ \\
\hline 3 & 7 \\
\hline
\end{tabular}




\section{KAIZEN : MANAGEMENT SYSTEMS \& INDUSTRIAL ENGINEERING JOURNAL VOL. 2 NO. 2 TEKNIK INDUSTRI UNIVERSITAS PGRI MADIUN}

Perhitungan rasio dilakukan melalui 3 kriteria. Kriteria produktivitas pada rasio 1 merupakan perbandingan kapasitas output produksi setiap satu bulan dengan jam kerja setiap satu bulan selama empat bulan. Kriteria produktivitas pada rasio 2 merupakan perbandingan kapasitas output produksi setiap satu bulan dengan jumlah tenaga kerja setiap bulan selama empat bulan. Kriteria produktivitas pada rasio 3 merupakan perbandingan kapasitas output produksi setiap satu bulan dengan energi listrik $(\mathrm{KWH})$ setiap satu bulan selama empat bulan. Hasil dari perhitungan kriteria dari 3 rasio dapat dilihat pada Tabel 7., Tabel 8. dan Tabel 9. Rasio minimum didapat dari nilai rasio yang terkecil. Rasio rata-rata didapat dari total rasio dibagi jumlah pengemasan. Rasio maksimum yang didapat dari nilai rasio yang terbesar.

Tabel 7 Hasil Perhitungan Rasio 1 Selama 4 Bulan

\begin{tabular}{|l|l|l|c|}
\hline \multicolumn{1}{|c|}{ Bulan } & Output Produk (Kg) & Jam Kerja (Jam) & Rasio 1 \\
\hline Juni 2018 & $2,934,500$ & 456 & $6,435.3$ \\
\hline Juli 2018 & $5,351,800$ & 624 & $8,576.6$ \\
\hline Agustus 2018 & $4,931,000$ & 576 & $8,560.8$ \\
\hline September 2018 & $4,965,000$ & 576 & $8,619.8$ \\
\hline Rasio Minimum & & $6,435.3$ \\
\hline Rasio Rata-rata & $8,048.1$ \\
\hline Rasio Maksimum & $8,619.8$ \\
\hline
\end{tabular}

Tabel 8. Hasil Perhitungan Rasio 2 Selama 4 Bulan

\begin{tabular}{|l|c|c|c|}
\hline \multicolumn{1}{|c|}{ Bulan } & Output Produk (Kg) & Tenaga Kerja (Orang) & Rasio 2 \\
\hline Juni 2018 & $2,934,500$ & 418 & $7,020.3$ \\
\hline Juli 2018 & $5,351,800$ & 418 & $12,803.3$ \\
\hline Agustus 2018 & $4,931,000$ & 418 & $11,796.7$ \\
\hline September 2018 & $4,965,000$ & 418 & $11,878.6$ \\
\hline Rasio Minimum & & $7,020.3$ \\
\hline Rasio Rata-rata & $10,874.6$ \\
\hline Rasio Maksimum & $12,803.7$ \\
\hline
\end{tabular}

Tabel 9. Hasil Perhitungann Rasio 3 Selama 4 Bulan

\begin{tabular}{|l|c|c|c|}
\hline \multicolumn{1}{|c|}{ Bulan } & Output Produk (Kg) & Listrik (KWH) & Rasio 3 \\
\hline Juni 2018 & $2,934,500$ & 72,520 & 40.5 \\
\hline Juli 2018 & $5,351,800$ & 116,823 & 45.8 \\
\hline Agustus 2018 & $4,931,000$ & 101,559 & 48.6 \\
\hline September 2018 & $4,965,000$ & 102,663 & 48.4 \\
\hline Rasio Minimum & 40.5 \\
\hline Rasio Rata-rata & 45.8 \\
\hline Rasio Maksimum & 48.6 \\
\hline
\end{tabular}

Pembentukan matriks sasaran dilakukan melalui 5 Tahapan. Tahapan dari matiks sasaran adalah penentuan nilai tahap awal, penentuan nilai rasio terendah, penentuan nilai sasaran, penentuan bobot untuk masing-masing kriteria dan bentuk Objective Matrix(OMAX).

1. Penentuan Nilai TahapAwal

Penentuan nilai tahap awal merupakan langkah pertama pembentukan matriks sasaran (objective matrix) yang akan digunakan untuk pengukuran produktivitas di PG Kremboong. Dalam matriks sasaran nilai tahap awal akan ditempatkan pada level 3. Berdasarkan nilai rata-rata pencapaian kinerja dari setiap rasio selama periode Juni 2018 sampai September 2018 yang menjadi dasar pengukuran, maka dapat ditentukan nilai tahap awal untuk masing- masing rasio yang menjadi indikator produktivitas di PG Kremboong yaitu seperti pada Tabel 10.

Tabel 10. Nilai Tahap Awal dari Setiap Rasio

\begin{tabular}{|c|c|c|}
\hline Rasio 1 & Rasio 2 & Rasio 3 \\
\hline $8,048.1$ & 10,874 & 45.8 \\
\hline
\end{tabular}

2. Penentuan Nilai RasioTerendah

Nilai rasio terendah menunjukkan kinerja terburuk dari setiap kriteria yang diperkirakan dapat terjadi pada saat kondisi operasi normal. Pada matriks sasaran nilai rasio terendah akan ditempatkan pada level 0 . level terendah yang disajikan 


\section{KAIZEN : MANAGEMENT SYSTEMS \& INDUSTRIAL ENGINEERING JOURNAL VOL. 2 NO. 2 TEKNIK INDUSTRI UNIVERSITAS PGRI MADIUN}

merupakan nilai rasio terburuk dari setiap kriteria selama periode Juni 2018 sampai Agustus 2018. Tabel 11. menunjukkan nilai rasio terendah

Tabel 11. Nilai Rasio Terendah

\begin{tabular}{|c|c|c|}
\hline Rasio 1 & Rasio 2 & Rasio 3 \\
\hline 6435.3 & $7,020.3$ & 40.5 \\
\hline
\end{tabular}

3. Penentuan Nilai Sasaran

Nilai sasaran ini merupakan nilai tertinggi dari setiap rasio dan menunjukkan performasi terbaik yang dapat dicapai selama rentang waktu yang akan datang. Dalam matriks sasaran, nilai ini akan ditempatkan pada level 10. Nilai rasio sasaran yang disajikan merupakan nilai rasio terbaik dari setiap kriteria selama periode Juni 2018 sampai September 2018. Tabel 12. menunukkan nilai rasio tertinggi.

Tabel 12. Nilai Rasio Tertinggi

\begin{tabular}{|c|c|c|}
\hline Rasio 1 & Rasio 2 & Rasio 3 \\
\hline $8,619.8$ & $12,803.7$ & 48.6 \\
\hline
\end{tabular}

4. Penentuan Bobot Untuk Masing-masing Kriteria

Nilai bobot dari setiap menunjukkan nilai atau prosentase prioritas dari usaha pengendalian dan peningkatan nilai rasio yang menjadi indikator produktivitas di PG Kremboong. Sesuai pada Tabel 6. nilai bobot yang diperoleh kemudian dikonversikan dalam skala $100 \%$ hasil pembagian yang telah dibulatkan dimasukkan kedalam matriks. Tabel 13 . menunjukkan nilai bobot tertinggi untuk masing-masing rasio. Pembobotan untuk masing-masing rasio adalah sebagai berikut:

Rasio $1=(8 / 22) \times 100 \%=36 \%$

Rasio $2=(7 / 22) \times 100 \%=32 \%$

Rasio $3=(7 / 22) \times 100 \%=32 \%$

Tabel 13. Nilai Bobot Tertinggi untuk Masing-Masing Rasio

\begin{tabular}{|c|c|c|}
\hline Rasio 1 & Rasio 2 & Rasio 3 \\
\hline 36 & 32 & 32 \\
\hline
\end{tabular}

5. Bentuk Objective Matrix(OMAX)

Pada model Objective Matrix (OMAX), level yang digunakan sebagai titik acuan terdiri dari 3 level, yaitu :

a. Level 0 : Nilai level 0 ditentukan berdasarkan nilai terendah.

b. Level 3 : Nilai level 3 ditentukan berdasarkan nilai tahap awal.

c. Level 10 : Nilai level 10 ditentukan berdasarkan nilai sasaran.

Perhitungan OMAX dilakukan menjadi dua tahapan yaitu awal dan keseluruhan. Tabel 14. menunjukkan perhitungan OMAX awal. Hasil dari performance indicator dari perhitungan OMAX awal adalah 300. Pehitungan performance indicator pada OMAX awal diperoleh dari $108+96+96=300$. Perhitungan OMAX keseluruhan dibedakan menjadi 4 tahapan. Tahapan itu dibedakan pada bulan juni 2018, juli 2018, agustus 2018 dan september 2018. Tabel 15. menunjukkan pengukuran produktivitas bulan juni 2018. Hasil dari OMAX bulan juni 2018 menunjukkan performance indicator dengan current $=36+64+64=164$, previous $=-$, dan index $=164$. Tabel 16 . menunjukkan pengukuran produktivitas bulan juli 2018. Hasil dari OMAX bulan juli 2018 menunjukkan performance indicator dengan current $=360+320+96=776$, previous $=164$ dan index $=100$. Tabel 17 . menunjukkan pengukuran produktivitas bulan agustus 2018. Hasil dari OMAX bulan agustus 2018 menunjukkan performance indicator dengan current $=324+192+320=836$, previous $=776$ dan index $=7.1$. Tabel 18 . menunjukkan pengukuran produktivitas bulan september 2018. Hasil dari OMAX bulan september 2018 menunjukkan performance indicator dengan current $=360+224+320=904$, previous $=836$ dan index $=7.5$.

Copyright (C) 2019, Kaizen : Management Systems \& Industrial Engineering Journal ISSN 15222-96806 (print), ISSN 155222-95973 (online) 
KAIZEN : MANAGEMENT SYSTEMS \& INDUSTRIAL ENGINEERING JOURNAL VOL. 2 NO. 2 TEKNIK INDUSTRI UNIVERSITAS PGRI MADIUN

Tabel 14. OMAX Awal (Nilai Produktivitas Standar)

\begin{tabular}{|c|c|c|c|}
\hline Rasio 1 & Rasio 2 & Rasio 3 & Productivity Criteria \\
\hline 8048.1 & 10874 & 45.8 & Performance \\
\hline 8619.8 & 12803.7 & 48.6 & 10 \\
\hline 8538.129 & 12528.03 & 48.2 & 9 \\
\hline 8456.457 & 12252.36 & 47.8 & 8 \\
\hline 8374.786 & 11976.69 & 47.4 & 7 \\
\hline 8293.114 & 11701.01 & 47 & 6 \\
\hline 8211.443 & 11425.34 & 46.6 & 5 \\
\hline 8129.771 & 11149.67 & 46.2 & 4 \\
\hline 8048.1 & 10874 & 45.8 & 3 \\
\hline 7510.5 & 9589.433 & 44.03333 & 2 \\
\hline 6972.9 & 8304.867 & 42.26667 & 1 \\
\hline 6435.3 & 7020.3 & 40.5 & 0 \\
\hline 3 & 3 & 3 & Score \\
\hline 36 & 32 & 32 & Weight \\
\hline 108 & 96 & 96 & Value \\
\hline
\end{tabular}

Tabel 15. OMAX Bulan Juni 2018

\begin{tabular}{|c|c|c|c|}
\hline Rasio 1 & Rasio 2 & Rasio 3 & Productivity Criteria \\
\hline 6435.3 & 7020.3 & 40.5 & Performance \\
\hline 8619.8 & 12803.7 & 48.6 & 10 \\
\hline 8538.129 & 12528.03 & 48.2 & 9 \\
\hline 8456.457 & 12252.36 & 47.8 & 8 \\
\hline 8374.786 & 11976.69 & 47.4 & 7 \\
\hline 8293.114 & 11701.01 & 47 & 6 \\
\hline 8211.443 & 11425.34 & 46.6 & 5 \\
\hline 8129.771 & 11149.67 & 46.2 & 4 \\
\hline 8048.1 & 10874 & 45.8 & 3 \\
\hline 7510.5 & 7019.433 & 40.533 & 2 \\
\hline 63.9 & 69.867 & 40.2567 & 0 \\
\hline 6335.3 & 6920.3 & 39.5 & Score \\
\hline 1 & 2 & 2 & Weight \\
\hline 36 & 32 & 32 & Value \\
\hline 36 & 64 & 64 & \\
\hline
\end{tabular}

Tabel 16. OMAX Bulan Juli 2018

\begin{tabular}{|c|c|c|c|}
\hline Rasio 1 & Rasio 2 & Rasio 3 & Productivity Criteria \\
\hline 8576.6 & 12803.3 & 45.8 & Performance \\
\hline 8619.8 & 12803.7 & 48.6 & 10 \\
\hline 8538.129 & 12528.03 & 48.2 & 9 \\
\hline 8456.457 & 12252.36 & 47.8 & 8 \\
\hline 8374.786 & 11976.69 & 47.4 & 7 \\
\hline 8293.114 & 11701.01 & 47 & 6 \\
\hline 8211.443 & 11425.34 & 46.6 & 5 \\
\hline 8129.771 & 11149.67 & 46.2 & 4 \\
\hline 8048.1 & 10874 & 45.8 & 3 \\
\hline 7510.5 & 9589.433 & 44.03333 & 2 \\
\hline 6972.9 & 8304.867 & 42.26667 & 1 \\
\hline 6435.3 & 7020.3 & 40.5 & Score \\
\hline 10 & 10 & 3 & Weight \\
\hline 36 & 32 & 32 & Value \\
\hline 360 & 320 & 96 & \\
\hline
\end{tabular}

Copyright (C) 2019, Kaizen : Management Systems \& Industrial Engineering Journal ISSN 15222-96806 (print), ISSN 155222-95973 (online) 


\section{KAIZEN : MANAGEMENT SYSTEMS \& INDUSTRIAL ENGINEERING JOURNAL VOL. 2 NO. 2 TEKNIK INDUSTRI UNIVERSITAS PGRI MADIUN}

Tabel 17. OMAX Bulan Agustus 2018

\begin{tabular}{|c|c|c|c|}
\hline Rasio 1 & Rasio 2 & Rasio 3 & Productivity Criteria \\
\hline 8560.8 & 11796.7 & 48.6 & Performance \\
\hline 8619.8 & 12803.7 & 48.6 & 10 \\
\hline 8538.129 & 12528.03 & 48.2 & 9 \\
\hline 8456.457 & 12252.36 & 47.8 & 8 \\
\hline 8374.786 & 11976.69 & 47.4 & 7 \\
\hline 8293.114 & 11701.01 & 47 & 6 \\
\hline 8211.443 & 11425.34 & 46.6 & 5 \\
\hline 8129.771 & 11149.67 & 46.2 & 4 \\
\hline 8048.1 & 10874 & 45.8 & 3 \\
\hline 7510.5 & 9589.433 & 44.03333 & 2 \\
\hline 6972.9 & 8304.867 & 42.26667 & 1 \\
\hline 6435.3 & 7020.3 & 40.5 & 0 \\
\hline 9 & 6 & 10 & Score \\
\hline 36 & 32 & 32 & Weight \\
\hline 324 & 192 & 320 & Value \\
\hline
\end{tabular}

Tabel 18. OMAX Bulan September 2018

\begin{tabular}{|c|c|c|c|}
\hline Rasio 1 & Rasio 2 & Rasio 3 & Productivity Criteria \\
\hline 8619.8 & 11878 & 48.4 & Performance \\
\hline 8619.8 & 12803.7 & 48.6 & 10 \\
\hline 8538.129 & 12528.03 & 48.2 & 9 \\
\hline 8456.457 & 12252.36 & 47.8 & 8 \\
\hline 8374.786 & 11976.69 & 47.4 & 7 \\
\hline 8293.114 & 11701.01 & 47 & 6 \\
\hline 8211.443 & 11425.34 & 46.6 & 5 \\
\hline 8129.771 & 11149.67 & 46.2 & 4 \\
\hline 8048.1 & 10874 & 45.8 & 3 \\
\hline 7510.5 & 9589.433 & 44.03333 & 1 \\
\hline 6972.9 & 8304.867 & 42.26667 & 0 \\
\hline 6435.3 & 7020.3 & 40.5 & Score \\
\hline 10 & 7 & 10 & Weight \\
\hline 36 & 32 & 32 & Value \\
\hline 360 & 224 & 320 & \\
\hline
\end{tabular}

Analisa pencapaian skor untuk masing-masing rasio yaitu analisis yang bertujuan untuk melihat skor masing- masing kriteria rasio produktivitas terhadap dibawah, tepat dan diatas performasi standar. Tabel 19. menunjukkan hasil perhitungan pencapaian skor sesuai dengan pengukuran produktvitas bulan Juni 2018 sampai September 2018. Dari pencapaian skor pada Tabel 19. dapat diketahui bahwa tingkat rasio produktivitas terbaik pada bulan September 2018, sedangkan tingkat rasio produktivitas terburuk terjadi pada bulan juni 2018. Pada bulan juli ini PG Kremboong mampu memaksimalkan hasil output produksi dan penggunaan waktu jam kerja secara efektif walaupun dengan menggunakan energi yang efisien.

Tabel 19. Pencapaian Skor

\begin{tabular}{|l|c|c|c|}
\hline \multicolumn{1}{|c|}{ Bulan } & $\begin{array}{c}\text { Rasio 1 } \\
\text { Jam Kerja }\end{array}$ & $\begin{array}{c}\text { Rasio 2 } \\
\text { Tenaga Kerja }\end{array}$ & $\begin{array}{c}\text { Rasio 3 } \\
\text { Listrik }\end{array}$ \\
\hline Juni 2018 & 1 & 2 & 2 \\
\hline Juli 2018 & 10 & 10 & 3 \\
\hline Agustus 2018 & 9 & 6 & 10 \\
\hline September 2018 & 10 & 6 & 10 \\
\hline Total & 30 & 24 & 26 \\
\hline
\end{tabular}

Copyright (C) 2019, Kaizen : Management Systems \& Industrial Engineering Journal ISSN 15222-96806 (print), ISSN $155222-95973$ (online) 


\section{KAIZEN : MANAGEMENT SYSTEMS \& INDUSTRIAL ENGINEERING JOURNAL VOL. 2 NO. 2 TEKNIK INDUSTRI UNIVERSITAS PGRI MADIUN}

Evaluasi tingkat produktivitas untuk masing-masing rasio yang bertujuan untuk melihat skor masing-masing kriteria rasio produktivitas terhadap dibawah, tepat dan diatas performasi standar. Tabel 20. menunjukkan hasil perhitungan pencapaian skor sesuai dengan pengukuran produktvitas bulan juni 2018 sampai September 2018. Dari Tabel 20. evaluasi tingkat produktivitas yang dapat dari perhitungan OMAX dapat diketahui bahwa produktivitas terbaik tejadi pada bulan September 2018 yaitu sebesar 904. Sedangkan untuk produktivitas terburuk terjadi pada bulan Juni 2018 yaitu sebesar 164. Dari nilai indeks perubahan terhadap produktivitas standar dapat diketahui bahwa produktivitas terbaik terjadi pada bulan September yaitu sebesar 201\%. Sedangkan untuk produktivitas terburuk terjadi pada bulan Juni 2018 yaitu sebesar -45\%. Dari nilai indeks perubahan terhadap produktivitas periode sebelumnya dapat diketahui bahwa produktivitas terbaik terjadi pada bulan Juli 2018 yaitu sebesar $375 \%$. Sedangkan untuk produktivitas yang terjadi pada bulan Agustus-September 2018 sama-sama memiliki nilai yaitu sebesar $8 \%$.

Tabel 20. Evaluasi Tingkat Produktivitas

\begin{tabular}{|c|c|c|c|}
\hline Bulan & $\begin{array}{c}\text { Overall Productivity } \\
\text { (OP) }\end{array}$ & $\begin{array}{c}\text { Nilai Indeks Perubahan } \\
\text { Terhadap Produktivitas } \\
\text { Standar }\end{array}$ & $\begin{array}{c}\text { Nilai Indeks Perubahan Terhadap } \\
\text { Produktivitas Periode } \\
\text { Sebelumnya }\end{array}$ \\
\hline Juni 2018 & 164 & $-45 \%$ & - \\
\hline Juli 2018 & 776 & $159 \%$ & $375 \%$ \\
\hline Agustus 2018 & 836 & $179 \%$ & $8 \%$ \\
\hline September 2018 & 904 & $201 \%$ & $8 \%$ \\
\hline
\end{tabular}

Penentuan diagram indeks produktivitas pada penelitian ini dilakukan melalui 3 tahapan. Tahapan dari diagram indeks produktivitas antara lain overall productivity, nilai indeks perubahan terhadap produktivitas standar dan nilai indeks perubahan terhadap produktivitas periode sebelumnya.

1. Overall Productivity

Gambar 1. dapat dilihat bahwa nilai yang berada dibawa nilai produktivitas standar terjadi pada bulan Juni 2018, sedangkan nilai yang berada diatas nilai produktivitas standar terjadi pada bulan September, Juni dan Juli. Pada bulan September mengalami peningkatan yang tajam dikarenakan pada bulan ini waktu hari kerja lebih banyak dari bulan sebelumnnya hasil produksi dan penggunaan listrik mencapai target. Untuk biaya pekerja pada masa giling terhitung satu bulan dan biaya untuk listrik, biaya operasional, biaya bahan baku mengalami kenaikan yang cukup ekstrim sehingga perubahan dari bulan Juni ke bulan Juli mengalami sebesar 904. Karena waktu pengerjaan yang lebih optimal dari bulan sebelumnya. Untuk bulan Juni Terjadi nilai yang rendah sebesar 164 karena waktu yang terbatas dari bulan berikutnya sehingga dari biaya bahan baku, biaya operasional. Perubahan indeks produktivitas ini terjadi dikarenakan yang paling berpengaruh adalah bahan baku tebu. Karena bahan baku tersebut mengalami perubahan ketersediaan.

\section{Overal Productivity}

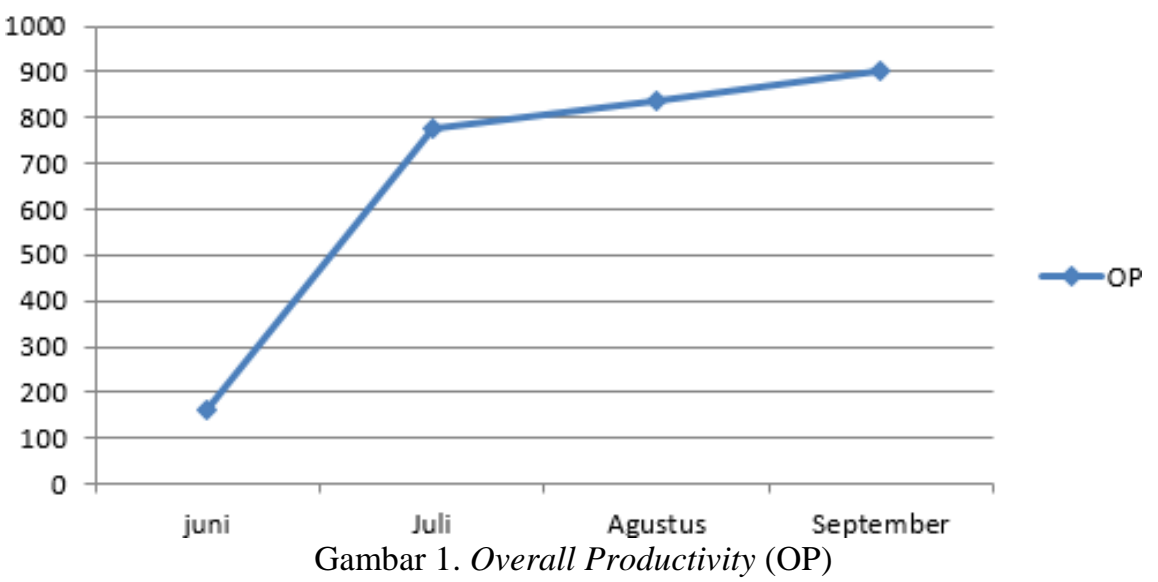

2. Nilai indeks Perubahan terhadap Produktivitas Standar

Gambar 2. dapat dilihat bahwa nilai yang berada dibawa nilai produktivitas standar terjadi pada bulan September, sedangkan nilai yang berada diatas nilai produktivitas standar terjadi pada bulan Juni. Perubahan dari produktivitas tiap bulan terjadi karena banyak faktor yang mempengaruhi diantaranya yaitu adanya jumlah output produk, energi listrik, jam kerja karyawan dimana setiap bulannya selalu berubah-ubah. Karena di bulan juni membutuhkan waktu yang sedikit sehingga Memerlukan bahan baku, waktu kerja, dan kebutuhan listrik yang lebih sedikit. Untuk biaya pekerja

Copyright (C) 2019, Kaizen : Management Systems \& Industrial Engineering Journal ISSN 15222-96806 (print), ISSN 155222-95973 (online) 


\section{KAIZEN : MANAGEMENT SYSTEMS \& INDUSTRIAL ENGINEERING JOURNAL VOL. 2 NO. 2 TEKNIK INDUSTRI UNIVERSITAS PGRI MADIUN}

pada masa giling terhitung satu bulan dan biaya untuk listrik, biaya operasional, biaya bahan baku mengalami kenaikan yang cukup ekstrim sehingga perubahan dari bulan Juni ke bulan Juli mengalami penurunan sebesar $-45 \%$ sebesar Untuk bulan Juli dan Agustus mengalami kenaikan sebesar 159\% dikarenakan mengalami penurun dari biaya bahan baku, biaya operasional. Perubahan indeks produktivitas ini terjadi dikarenakan yang paling berpengaruh adalah bahan baku tebu. Karena bahan baku tersebut mengalami perubahan ketersediaan.

\section{Nilai indeks Perubahan terhadap Produktivitas}

\section{Standar}

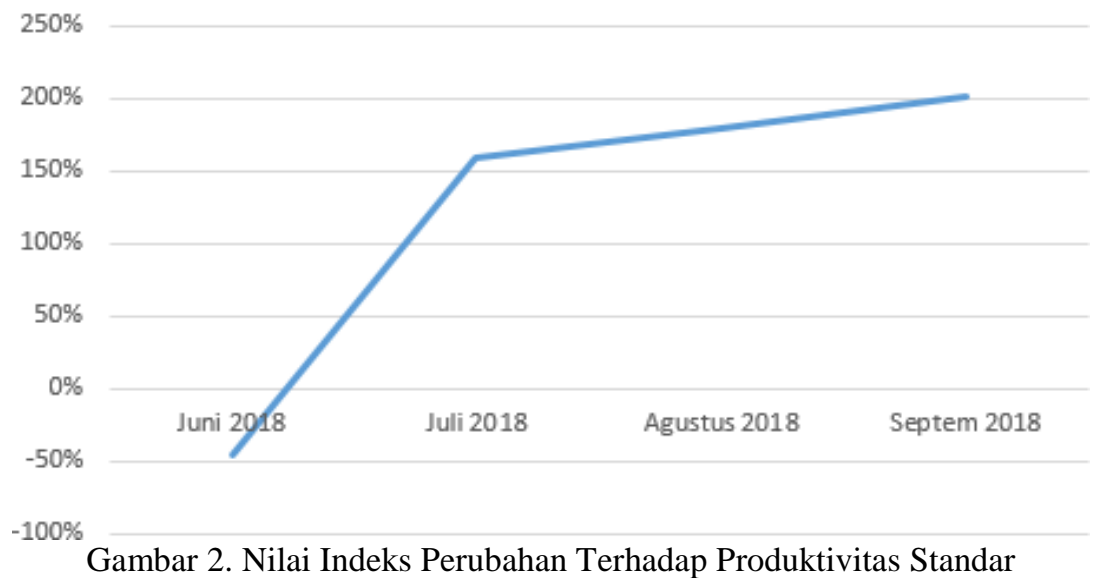

3. Nilai Indeks Perubahan Terhadap Produktivitas Periode Sebelumnya

Gambar 2. dapat dilihat bahwa nilai yang berada dibawa nilai produktivitas standar terjadi pada bulan Juni, sedangkan nilai yang berada diatas nilai produktivitas standar terjadi pada bulan Juli. Perubahan dari produktivitas tiap bulan terjadi karena banyak faktor yang mempengaruhi diantaranya yaitu adanya jumlah output produk, energi listrik, jam kerja karyawan dimana setiap bulannya selalu berubah-ubah. Pada bulan Juli mengalami peningkatan yang tajam dikarenakan pada bulan ini waktu hari kerja lebih banyak dari bulan sebelumnnya hasil produksi dan penggunaan listrik mencapai target. Untuk biaya pekerja pada masa giling terhitung satu bulan dan biaya untuk listrik, biaya operasional, biaya bahan baku mengalami kenaikan yang cukup ekstrim sehingga perubahan dari bulan Juni ke bulan Juli mengalami sebesar 375\%. Untuk bulan Agustus mengalami penurunan dikarenakan terjadi penurunan dari biaya bahan baku, biaya operasional. Perubahan indeks produktivitas ini terjadi dikarenakan yang paling berpengaruh adalah bahan baku tebu. Karena bahan baku tersebut mengalami perubahan ketersediaan.

Nilai Indeks Perubahan Terhadap Produktivitas
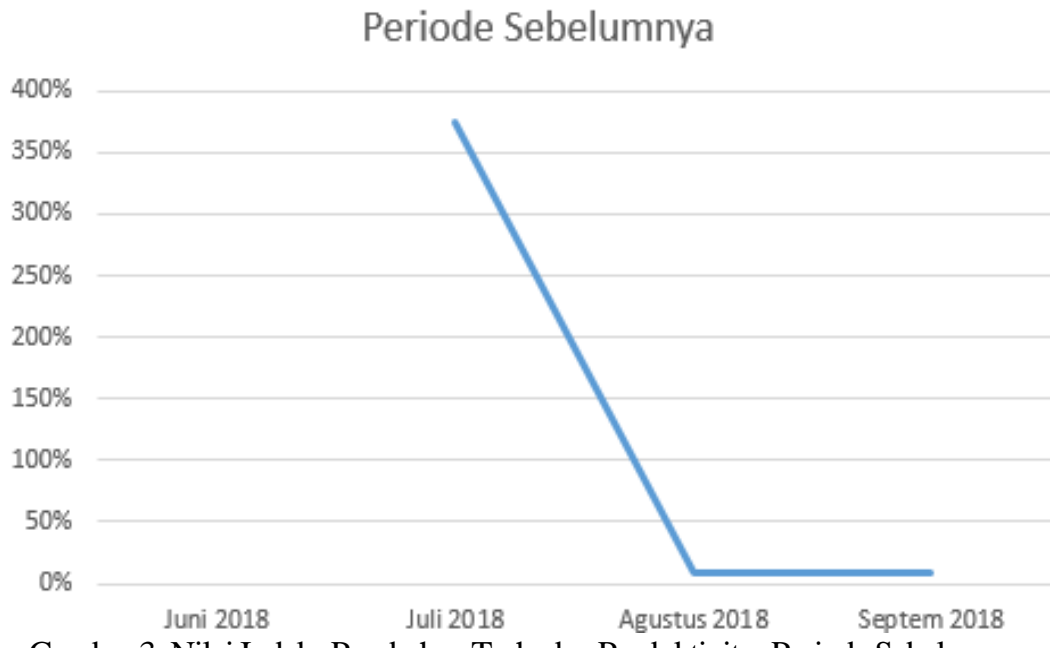

Gambar 3. Nilai Indeks Perubahan Terhadap Produktivitas Periode Sebelumnya

Copyright (C) 2019, Kaizen : Management Systems \& Industrial Engineering Journal ISSN 15222-96806 (print), ISSN 155222-95973 (online) 


\section{KAIZEN : MANAGEMENT SYSTEMS \& INDUSTRIAL ENGINEERING JOURNAL VOL. 2 NO. 2 TEKNIK INDUSTRI UNIVERSITAS PGRI MADIUN}

\section{Simpulan}

Berdasarkan hasil analisis dan pembahasan yang dilakukan maka dapat disimpulkan bahwa dari analisa produktivitas di PG Kremboong bagian pengolahan dengan menggunakan metode OMAX maka dapat diketahui indeks produktivitas terbaik tejadi pada bulan september 2018 yaitu sebesar 904. Sedangkan untuk produktivitas terburuk terjadi pada bulan Juni 2018 yaitu sebesar 164. Indeks perubahan terhadap produktivitas standar dapat diketahui bahwa produktivitas terbaik terjadi pada bulan September 2018 yaitu sebesar 201\%. Sedangkan untuk produktivitas terburuk terjadi pada bulan Juni 2018 yaitu sebesar $-45 \%$. Indeks perubahan terhadap produktivitas periode sebelumnya dapat diketahui bahwa produktivitas terbaik terjadi pada bulan Juli 2018 yaitu sebesar 375\%. Sedangkan untuk produktivitas yang terjadi pada bulan AgustusSeptember 2018 sama-sama memiliki nilai yaitu sebesar $8 \%$. Langkah perbaikan produktivitas guna perencanaan peningkatan produktivitas dimasa yang akan datang adalah dengan cara memprioritaskan kepada rasio yang memiliki nilai paling buruk untuk ditingkatkan melalui 3 tahapan peningkatan. Peningkatakan rasio 1, yaitu dengan efisiensi penggunaan jumlah tenaga kerja dan mengatur jadwal jam kerja dengan tepat sehingga memaksimalkan output gula yang dihasilkan. Peningkatan rasio 2 , yaitu dengan memberikan pelatihan-pelatihan tentang penggunaan mesin sesuai dengan spesifikasi mesin dan waktu kerja mesin nya dan pemberian penghargaan kepada karyawan yang mencapai target. Peningkatan Rasio 3, yaitu dengan menggunakan energi yang seefisien mungkin sehingga dapat mengurangi energi yang dibutuhkan.

\section{Daftar Pustaka}

[1] W. I. Ervianto, Manajemen Proyek Kontruksi. Yogyakarta: Andi Offset, 2004.

[2] P. Mali, Improving Total Productivity. London: Jhon Wiley \& Sound, 1978.

[3] F. Agustina and N. A. Riana, "Analisis Produktivitas dengan Metode Objective Matrix (OMAX) di PT. X," J. Tek. dan Manaj. Ind., vol. 6, no. 2, pp. 150-158, 2011.

[4] R. J., Produktivitas dan Manajemen. Jakarta: Dewan produktivitas nasional dan The Asia Foundation, 1985.

[5] V. Gaspersz, Manajemen Produktivitas Total. Jakarta: Gramedia Pustaka Utama, 1998.

[6] D. Sumanth., Productivity Engineering and Mangement. New York: Mc Graw Hill Book Company, 1995.

[7] F. Tania and M. Ulkhaq, "Pengukuran dan Analisis Produktivitas di PT. Tiga Manunggal Synthetic Industries dengan Menggunakan Metode Objective Matrix ( OMAX )," Ind. Eng. Online J., vol. 5, no. 4, pp. $1-9,2016$. 